\title{
EFFECT OF BIOSYNTHESIZED SILVER NANOPARTICLES ON
}

\section{MORPHOPHYSIOLOGY OF HOST}

\section{PRANJAL KR KAMAN, SARODEE BORUAH, HIMADRI KAUSHIK \& PRANAB DUTTA}

Department of Plant Pathology, Assam Agricultural University, Jorhat, Assam, India

Phytotoxicity is an important aspects of nanoparticles in relation to the environment and plants. Here, we report on the effects of biologically synthesized silver nanoparticles (Ag NPs) from Trichoderma asperellum on the development of Mustard, Chili, and French bean. Four toxicity indicators (seed germination, root and shoot length Chlorophyll content and Lipid peroxidation) were quantified following exposure to each nanoparticle at a concentrationof 1000ppm, 500ppm, 100ppm, 50ppm, 20ppm, 10ppm, 7ppm, 5ppm, 3ppm, 1ppm and carbendazim @0.3\%. Results showed that silver nanoparticles at a concentration of $100 \mathrm{ppm}$ and 50ppm effective in increasing all the growth parameters of the crops as compared to other concentration and carbendazim whereas it showed detrimental effects at a concentration of 1000 ppm.
\end{abstract}

KEYWORDS: Phytotoxicity, Nanoparticle \& Growth Parameters

Received: Feb 19, 2018; Accepted: Mar 12, 2018; Published: Apr 23, 2018; Paper Id.: IJBRJUN20181

\section{INTRODUCTION}

Recent applications of nanoparticles have concerns over the phytotoxic effect on plant health. Various reports said about the positive and negative aspects of nanoparticles on plant growth. Among positive effects, soybean germination and growth were promoted by a mixture of nano-sized silicon dioxide $\left(\mathrm{nSiO}_{2}\right)$ and nano-titanium dioxide $\left(\mathrm{nTiO}_{2}\right)$ at low concentrations, which increased nitrate reductase activity, enhanced the ability to absorb water and fertilizer, and stimulated the antioxidant system ( $\mathrm{Lu}$ et al., 2002). The addition of $\mathrm{nTiO}_{2}$ of 2.5 to $40 \mathrm{~g} / \mathrm{kg}$ of soil promoted the growth of spinach, likely by protecting the chloroplasts from ageing during long-term illumination (Hong et al., 2005; Zheng et al., 2005). Similarly, $\mathrm{nSiO}_{2}$ enhanced the growth of Changbai larch (Larix olgensis), and the enhancement, increased with the $\mathrm{nSiO}_{2}$ concentration up to $500 \mathrm{mg} / \mathrm{L}$ (Lin et al., 2004). In contrast, root growth inhibition by $2,000 \mathrm{mg} / \mathrm{L}$ nano-aluminum oxide $\left(\mathrm{nAl}_{2} \mathrm{O}_{3}\right)$ was reported for five plant species: corn, cucumber, soybean, cabbage, and carrot (Yang and Watts 2005). But still, there is a gap in the phytotoxic effect of nanoparticles on morphophysiology effect on the plant. Here in this experiment, an effort was made to study the effect of biologically synthesized Ag NPs on the plant growth parameters.

\section{MATERIALS AND METHODS}

Source of Silver Nanoparticles

Biologically synthesized Ag NPs was collected from Deptt of Plant Pathology size 27.64nm, charge -1.34 MV and crystalline cubic in nature

\section{Source of Seeds}

Seeds of Mustard, Chili, and French bean were collected from the local market. 


\section{Seed Treatment}

Seeds were treated at a concentration of 1000ppm, 500ppm, 100ppm, 50ppm, 20ppm, 10ppm, 7ppm, 5ppm, 3ppm, 1ppm of Ag NPs and carbendazim @0.3\% in a beaker and kept for 1hrs.

\section{Plant Growth Conditions}

The treated seeds were grown in plastic trays by using a cocopit and kept in a greenhouse condition for 25 days.

\section{Chlorophyll Content}

Chlorophyll content was determined by the acetone method. The following calculations will be made to ascertain sample chlorophyll concentrations.

Chlorophyll a [milligrams/milliliter $(\mathrm{mg} / \mathrm{ml})]=12.7$ (A) $663-2.69$ (A) 645

Chlorophyll b $(\mathrm{mg} / \mathrm{ml})=22.9(\mathrm{~A}) 645-4.68(\mathrm{~A}) 663$

Where: (A) $645=$ absorbance at a wavelength of $645 \mathrm{~nm}$; (A) $663=$ absorbance at a wavelength of $663 \mathrm{~nm}$.

\section{Lipid Peroxidation}

$0.5 \mathrm{~g}$ leaf sample was homogenized in $10 \mathrm{ml}$ of trichloroacetic acid (TCA) and centrifuged at $15000 \mathrm{~g}$ for $5 \mathrm{~min}$. From this $2 \mathrm{ml}$ of the supernatant and $4 \mathrm{ml}$ of $0.5 \%$ tribarbutric acid (TBA) in $20 \%$ of TCA was mixed.The mixture was heated at $95^{\circ} \mathrm{C}$ for $30 \mathrm{~min}$ and cool at ice bath. Again, it was centrifuged at $1000 \mathrm{~g}$ for $5 \mathrm{~min}$. Record the absorbance at $532 \mathrm{~nm}$ and $600 \mathrm{~nm}$.

\section{Measurements of Toxic Effects}

Germination percentage, root and shoot length, chlorophyll content and lipid peroxidation was measured after 25 days of planting.

\section{RESULTS AND DISCUSSIONS}

\section{Seed Germination}

Seed germination was found to be increased with the decreased in the concentration of silver nanoparticles. Seed germination percentage was found to be highest at a concentration of $100 \mathrm{ppm}(100 \%)$ and carbendazim (43.25) at the recommended dose in all the crops. (Figure.1)

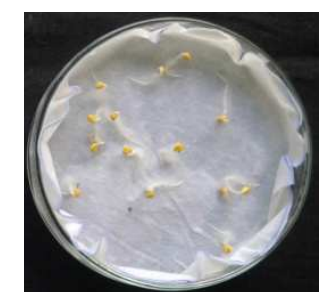

Figure 1 (a): Seed Treatment of a French Bean with Ag NPs 


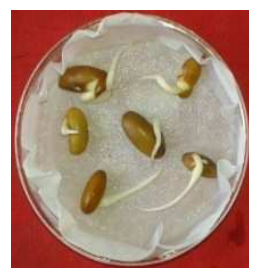

Figure 1(b): Seed Treatment of Mustard with Ag NPs

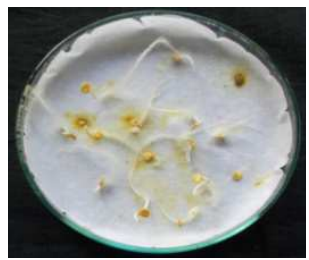

Figure 1(c): Seed Treatment of Chili with Ag NPs

\section{Root Length and Shoot Length}

A similar trend was observed in case of root and shoot length that is with decreased in the concentration of Ag NPs the root length and shoot length increases as compared to the carbendazim and control. Root length was found to be $10 \mathrm{~cm}$ in case of French bean, $5.2 \mathrm{~cm}$ in Mustard and $6.2 \mathrm{~cm}$ in Chili and shoot length of 20cm in French bean, in Mustard $9 \mathrm{~cm}$ and in Chili $6.4 \mathrm{~cm}$ at a concentration of $100 \mathrm{ppm}$ as compared to control $(6.0,3.3$ and $2.8 \mathrm{~cm})$ and in carbendazim (7.9, 3.4 and $4.2 \mathrm{~cm})$ root length and shoot length $(6.0 \mathrm{~cm}, 5.4 \mathrm{~cm}$ and $3 \mathrm{~cm})$ and in carbendazim $(8.6 \mathrm{~cm}, 7.2 \mathrm{~cm}$ and $4.0 \mathrm{~cm})$ whereas at $1000 \mathrm{ppm}$ concentration it was found to be decreased in both the root and shoot length. The mechanism responsible for enhanced root and elongation is unclear. Thus we can report the minimal toxicity of silver nanoparticles on the tested plants, this is a good evidence for demonstrating response of Ag NPs in Mustard, Chili, and French bean in a limited range (100ppm), above which toxic levels are reached causing subsequent declines in growth. These results agree with Mahajan et al. (2011); Mihaela and Dorina (2007) and Seif et al. (2011)

\section{Chlorophyll Content}

Chlorophyll content was found to be highest at a concentration of $100 \mathrm{ppm}$, followed by control and carbendazim treatment. Chlorophyll 'a' content in French bean was found to be $0.118 \mathrm{mg} / 1$ at $100 \mathrm{ppm}$ concentration of Ag NPs and in control $0.107 \mathrm{mg} / 1$ and in carbendazim $0.037 \mathrm{mg} / \mathrm{l}$. Similarly, in case mustard and chili Chlorophyll 'a' content was $0.018 \mathrm{mg} / \mathrm{l}$ and $0.123 \mathrm{mg} / \mathrm{l}$ at a $1000 \mathrm{ppm}$ concentration of $\mathrm{Ag}$ NPs and in control $0.004 \mathrm{mg} / \mathrm{l}$ and $0.006 \mathrm{mg} / \mathrm{l}$ and in carbendazim $0.03 \mathrm{mg} / \mathrm{l}$ and $0.07 \mathrm{mg} / \mathrm{l}$.

Chlorophyll 'b' content was found to be $0.183 \mathrm{mg} / \mathrm{l}$ in French bean, $0.081 \mathrm{mg} / \mathrm{l}$ in the mustard and 0.551 in chili.

The increase in the chlorophyll content might be due to the deposition of Ag NPs in the plant cell. The findings are similar to the results obtained from other studies (Karthick and Chitrakala, 2011), they demonstrated that chlorophyll A content was significantly increased by silver nanoparticles in green gram and sorghum. In other studies, response of corn (Zea mays) seedlings to the administration of 20, 40, 60, 80 and $100 \mu \mathrm{l} / 1$ of $\mathrm{Fe}_{3} \mathrm{O}_{4}$ nanoparticles suspension concentration resulted in the diminution of chlorophyll ratio, while Cucurbita pepo seedlings exhibited a slight increase of chlorophyll contents (Racuciu et al., 2009). Studies also demonstrated that $\mathrm{TiO}_{2}$ nanoparticles promoted photosynthesis and nitrogen metabolism, and thus the greatly improved growth of spinach at a concentration as low as $20 \mathrm{mg} / \mathrm{l}$ (Hong et al., 2005 and Zheng et al., 2005) 


\section{Lipid Peroxidation}

In case of French bean, lipid peroxidation was found to be $185.80 \mathrm{~mol} / \mathrm{cm}$, in mustard $128.9 \mathrm{~mol} / \mathrm{cm}$ and chili $332.12 \mathrm{~mol} / \mathrm{cm}$ at a concentration of 100ppm as compared to control $122.16 \mathrm{~mol} / \mathrm{cm}, 9.2 \mathrm{~mol} / \mathrm{cm}$ and $141.67 \mathrm{~mol} / \mathrm{cm}$. The exact mechanism how Ag NPs increased or decreased in the lipid peroxidation is not known.

\section{CONCLUSIONS}

The present study demonstrated the effect of silver nanoparticles on crop plant species Mustard, Chili, and French bean. The presence of AgNPs affects the growth of Mustard, Chili, and French bean at different concentrations. The maximum effect was found at $100 \mathrm{ppm}$ for the three crop plants. Beyond this concentration, the growth was inhibited (1000ppm). The effective growth at certain optimum concentration and inhibited growth beyond this concentration may be attributed to the accumulation and uptake of AgNPs by the roots. It was found that the accumulation and uptake of nanoparticles were dependent on the exposure concentration

\section{REFERENCES}

1. Hong, F. S. ; Yang, F. ; Liu, C. ; Gao, Q.; Wan, Z.; Gu, F.; Wu, C.; Ma, Z.; Zhou, J. and Yang P. (2005). Influence of nano$\mathrm{TiO}_{2}$ on the chloroplast aging of spinach under light. Biol. Trace. Elem. Res. 104:249-260.

2. Karthick S, Chitrakala K (2011) Ecotoxicological effect of Lecani cilium Lecanii (Ascomycota:Hypocereales) based silver nanoparticles on growth parameters of economically important plants. J. of. Biopes. 4 (1): 97 - 101.

3. Lu, C. M. ; Zhang,C. Y. ; Wen, J. Q. ; Wu,G.R and Tao, M. X. (2002). Research of the effect of nanometer materials on germination and growth enhancement of Glycine max and its mechanism. Soy. Sci. 21: 168-172.

4. Mahajan, P.; Dhoke, S. K and Khanna, A. S. (2011). Effect of nano - ZnO particle suspension on growth of Mung (Vigna radiata) and Gram (Ccicer arietinum) seedling using plant agar method. J. Of. Nanotech. 1(1) : 1-7.

5. Mihaela R, Dorina EC (2007). TMA-OH coated magnetic nanoparticles internalizes in vegetal tissue. Rom. J. Phys. (52): 395 $-420$

6. Lin, B. S,; Diao, S.Q.; Li, C. H.; Fang, L.J.; Qiao, S.C. and Yu M. (2004). Effect of TMS (nanostructured silicon dioxide) on growth of Changbai Larch seedlings. J. For. Res. CHN 15:138-140.

7. MOUSSAOUI, NORA, et al. "INTERACTION BETWEEN HOST-PLANT AND FORMICIDAE IN THE CENTRALE MITIDJA (ALGERIA)." International Journal of Agricultural Science and Research (IJASR) 4.5 (2014): 67-75

8. Racuciu M, Creanga D, Olteanu Z (2009). Water based magnetic fluid impact on young plants growing. Rom. Rep. Phys. 61 (2): 259-268.

9. Seif SM, Sorooshzadeh A, Rezazadehs H, Naghdibadi HA (2011). Effect of nanosilver and silver nitrate on seed yield of borage. Jour. Medic. Plant Res. 5 (2): 171 - 175.

10. Yang, L and Watts, D. J. (2005). Particle surface characteristics may play an important role in phytotoxicity of alumina nanoparticles. Toxicol. Lett. 158:122-132

11. Zheng L.; Hong, F.; Lu, S. and Liu C. (2005). Effect of nano-TiO ${ }_{2}$ on strength of naturally aged seeds and growth of spinach. Biol. Trace. Elem. Res. 104:83-91. 